\title{
A Study on the Effect of Intervention on College Students' Psychological Crisis by case Analysis
}

\author{
Huanquan Shen \\ Qiqihar Medical University, Heilongjiang 161006 \\ Basic Medical University \\ Qiqihar Medical University, Bukui North Street, Jianhua District, Qiqihar City, Heilongjiang Province \\ 15904523297 \\ an99004@126.com
}

Keywords: Mental health; Case analysis; University student; The effect of intervention

\begin{abstract}
Object: through case analysis to study the effect of intervention on College students' Psychological crisis, and exploring the best teaching mode. Method: Students in grade 2017 in our school were selected to the case analysis. Four classes were selected by random cluster sampling. Total 89 students from two class were used as the experimental group for case analysis, and 92 students from the other two classes were the control group. Mental Health scale for Chinese College students (CCSMHS) and self-made simple satisfaction scale were adopted for the determine and review of the two groups of students. Results: Before the intervention, there was no difference in the score of CCSMHS between the two groups, $P>0.05$. After the intervention, compared with the control group, all the factors in the experimental group were significantly lower, and the difference was statistically different, $P<0.05$. The degree of satisfaction and the satisfaction with self-help are $98.88 \%$ in the experimental group, and compared with the control group, the increase was significant, and the difference was statistically significant, $P<0.05$. Conclusion: Case analysis was applied in the mental health of college students, and it can improve the students' mental health and improve the effect of intervention.
\end{abstract}

With the rapid development of economy and society, the rhythm of people's lives is quickening, and the pressure of social competition is increasing. The ethics, values and behaviors of college students were under unprecedented impact, and the incidence of psychological problems and mental illness was kept increasing [1]. Since the 1990s, suicide incidents of college students are becoming increasingly prominent, and natural disasters and man-made disasters were occurred frequently. The psychological crisis of college students and the malignant events caused by the psychological crisis of college students were on the rising. At present, the psychological crisis of college students has aroused the general concern of the society, and has become one of the factors that affect the growth of college students and the stability of colleges and universities [2]. However, due to the late start of research and practice on psychological crisis intervention of college students in China, and the construction of the system is not yet perfect, thus the methods and measures of College students' Psychological crisis intervention should be improved. Therefore, we should strengthen the research on the psychological crisis intervention of college students in our country, and constructed the intervention system of the psychological crisis of college students, and strengthen the intervention measures for the psychological crisis of college students, whether it is to the individual development and talent development of college students. It is also of great significance to maintain harmony and stability in colleges and universities.

\section{Research Object and Method}

\section{Research Object}

Students in grade 2017 in our school were selected for the study on the practice of experiential teaching method of mental health course. Four classes were selected by random cluster sampling. 
Total 89 students from two class were used as the experimental group for case analysis, and 92 students from the other two classes were the control group. There were 42 boys and 47 girls in the experimental group, with an average age of $18.21 \pm 0.56$. And there were 45 boys and 47 girls in the control group, with an average age of $18.25 \pm 0.61$. There was no difference in sex and age between the two groups, with good comparability.

\section{Research Method}

Mental Health scale for Chinese College students (CCSMHS) and self-made simple teaching effective evaluation scale were adopted for the teaching effective evaluation. CCSMHS was made by Zheng richang, with good reliability and validity, which is the testing tool of Chinese college students' mental health evaluation system under the ministry of education of the people's republic of China [3]. Including a total of 12 evaluation factors, and a 5-level scoring method with 1-5 points. Self-made simple teaching effective evaluation scale has been used for many years in our school. It is mainly used to investigate the students' satisfaction with the teaching effect and their own help, the total score was $100, \geq 90$ means very satisfaction, 76-90 means satisfaction, 60-75 means commonly, $<60$ means no satisfaction.

\section{Case analysis Method}

Before the experimental group was treated with case analysis, organize relevant teachers to consult for topics of interest or psychological issues to current college students. And collected and organized by questionnaire, then the themes were screened and identified by the teachers of psychology major in our school, obtained 9 case analysis themes showed in table 1 . And adjust the case analysis to the mode of combining the theory and experience, among them, the theory takes the form of a lecture and showed by microsoft office powerpoint (PPT) and other multimedia technology. The experience is changed to small class analysis, and taking the participatory interactive model as the main model, and adding the diary of psychological growth to record and reflect on their own psychological growth.

Table 1 Case analysis themes and contents

\begin{tabular}{ll}
\hline Case analysis themes & Main contents \\
\hline Partnership building team & Warm-up activity, team specification and \\
sit up & $\begin{array}{l}\text { Phrase making sentence, emotion abreact } \\
\text { and management and relaxation exercise }\end{array}$ \\
Management emotion & $\begin{array}{l}\text { Set learning goals and cultivate } \\
\text { perseverance }\end{array}$ \\
Learning psychology & The course of growth \\
Coping with stress and frustration & Pass on trust and take responsibility \\
Interpersonal interaction & The last days of life and my epitaph \\
Life education & To know oneself correctly and build the \\
The cultivation of self-consciousness & good banks \\
& Love value auction and organization \\
Sexual relations & debates about premarital sex \\
& Movie viewing and case analysis \\
\hline
\end{tabular}

\section{Statistical Analysis}

All the data in this study were analyzed by spss17.0, $P<0.05$ means there is a statistical difference.

\section{Results}

\section{CCSMHS Score Comparison between the Two Groups}

Before the intervention, there was no difference in the score of CCSMHS between the two groups, $P>0.05$. After the intervention, compared with the control group, all the factors in the experimental 
group were significantly lower and the difference was statistically different, $P<0.05$. The results were showed in table 2 and 3.

Table 2 CCSMHS score comparison between the two groups before the intervention

\begin{tabular}{|c|c|c|c|c|c|c|c|c|c|c|c|c|}
\hline $\begin{array}{l}\text { Gro } \\
\text { up }\end{array}$ & $\begin{array}{l}\text { Somatic } \\
\text { factor }\end{array}$ & $\begin{array}{l}\text { Impulse } \\
\text { factor }\end{array}$ & $\begin{array}{l}\text { Depen } \\
\text { dency } \\
\text { factor }\end{array}$ & $\begin{array}{l}\text { Sexual } \\
\text { psych } \\
\text { ologic } \\
\text { al } \\
\text { disord } \\
\text { er } \\
\text { factor }\end{array}$ & $\begin{array}{l}\text { Forcin } \\
\mathrm{g} \\
\text { factor }\end{array}$ & $\begin{array}{l}\text { Depre } \\
\text { ssion } \\
\text { factor }\end{array}$ & $\begin{array}{l}\text { Anxiet } \\
\mathrm{y} \\
\text { factor }\end{array}$ & $\begin{array}{l}\text { Social } \\
\text { withdr } \\
\text { awal } \\
\text { factor }\end{array}$ & $\begin{array}{l}\text { Social } \\
\text { attack } \\
\text { factor }\end{array}$ & $\begin{array}{l}\text { Inferio } \\
\text { rity } \\
\text { factor }\end{array}$ & $\begin{array}{l}\text { Parano } \\
\text { ia } \\
\text { factor }\end{array}$ & $\begin{array}{l}\text { Psych } \\
\text { otic } \\
\text { factor }\end{array}$ \\
\hline $\begin{array}{l}\text { Exp } \\
\text { eri } \\
\text { men } \\
\text { tal } \\
\text { gro } \\
\text { up }\end{array}$ & $\begin{array}{l}45.23 \pm 8 \\
45\end{array}$ & $\begin{array}{l}46.23 \pm 5 \\
32\end{array}$ & $\begin{array}{l}48.31 \pm \\
9.02\end{array}$ & $\begin{array}{l}45.11 \pm \\
6.42\end{array}$ & $\begin{array}{l}45.26 \pm \\
6.38\end{array}$ & $\begin{array}{l}48.31 \pm \\
7.24\end{array}$ & $\begin{array}{l}49.30 \pm \\
8.25\end{array}$ & $\begin{array}{l}47.28 \pm \\
6.34\end{array}$ & $\begin{array}{l}43.01 \pm \\
4.32\end{array}$ & $\begin{array}{l}47.16 \pm \\
5.42\end{array}$ & $\begin{array}{l}46.15 \pm \\
6.31\end{array}$ & $\begin{array}{l}46.10 \pm \\
7.11\end{array}$ \\
\hline $\begin{array}{l}\text { Con } \\
\text { trol } \\
\text { gro } \\
\text { up } \\
\end{array}$ & $\begin{array}{l}45.57 \pm 8 \\
48\end{array}$ & $\begin{array}{l}46.42 \pm 5 \\
11\end{array}$ & $\begin{array}{l}47.81 \pm \\
9.32\end{array}$ & $\begin{array}{l}45.37 \pm \\
6.41\end{array}$ & $\begin{array}{l}45.62 \pm \\
6.36\end{array}$ & $\begin{array}{l}48.57 \pm \\
7.22\end{array}$ & $\begin{array}{l}49.61 \pm \\
8.27\end{array}$ & $\begin{array}{l}47.59 \pm \\
6.37\end{array}$ & $\begin{array}{l}43.13 \pm \\
4.31\end{array}$ & $\begin{array}{l}47.65 \pm \\
5.40\end{array}$ & $\begin{array}{l}46.58 \pm \\
6.30\end{array}$ & $\begin{array}{l}46.57 \pm \\
7.21\end{array}$ \\
\hline
\end{tabular}

Table 3 CCSMHS score comparison between the two groups after the intervention

\begin{tabular}{|c|c|c|c|c|c|c|c|c|c|c|c|c|}
\hline $\begin{array}{l}\text { Gro } \\
\text { up }\end{array}$ & $\begin{array}{l}\text { Somatic } \\
\text { factor }\end{array}$ & $\begin{array}{l}\text { Impulse } \\
\text { factor }\end{array}$ & $\begin{array}{l}\text { Depe } \\
\text { ndenc } \\
\mathrm{y} \\
\text { factor }\end{array}$ & $\begin{array}{l}\text { Sexua } \\
1 \\
\text { psych } \\
\text { ologi } \\
\text { cal } \\
\text { disor } \\
\text { der } \\
\text { factor }\end{array}$ & $\begin{array}{l}\text { Forci } \\
\mathrm{ng} \\
\text { factor }\end{array}$ & $\begin{array}{l}\text { Depre } \\
\text { ssion } \\
\text { factor }\end{array}$ & $\begin{array}{l}\text { Anxie } \\
\text { ty } \\
\text { factor }\end{array}$ & $\begin{array}{l}\text { Socia } \\
1 \\
\text { withd } \\
\text { rawal } \\
\text { factor }\end{array}$ & $\begin{array}{l}\text { Socia } \\
1 \\
\text { attack } \\
\text { factor }\end{array}$ & $\begin{array}{l}\text { Inferi } \\
\text { ority } \\
\text { factor }\end{array}$ & $\begin{array}{l}\text { Paran } \\
\text { oia } \\
\text { factor }\end{array}$ & $\begin{array}{l}\text { Psych } \\
\text { otic } \\
\text { factor }\end{array}$ \\
\hline $\begin{array}{l}\text { Ex } \\
\text { peri } \\
\text { me } \\
\text { ntal } \\
\text { gro } \\
\text { up }\end{array}$ & $\begin{array}{l}41.24 \pm 7 \\
.25\end{array}$ & $\begin{array}{l}41.02 \pm 5 \\
.00\end{array}$ & $\begin{array}{l}43.24 \\
\pm 7.52\end{array}$ & $\begin{array}{l}42.35 \\
\pm 5.21\end{array}$ & $\begin{array}{l}43.13 \\
\pm 5.78\end{array}$ & $\begin{array}{l}41.01 \\
\pm 6.44\end{array}$ & $\begin{array}{l}41.26 \\
\pm 7.05\end{array}$ & $\begin{array}{l}42.12 \\
\pm 5.24\end{array}$ & $\begin{array}{l}38.22 \\
\pm 5.29\end{array}$ & $\begin{array}{l}41.07 \\
\pm 6.28\end{array}$ & $\begin{array}{l}42.78 \\
\pm 5.29\end{array}$ & $\begin{array}{l}40.23 \\
\pm 5.20\end{array}$ \\
\hline $\begin{array}{l}\text { Co } \\
\text { ntr } \\
\text { ol } \\
\text { gro } \\
\text { up }\end{array}$ & $\begin{array}{l}44.77 \pm 7 \\
.88^{\wedge}\end{array}$ & $\begin{array}{l}45.11 \pm 5 \\
.42^{\wedge}\end{array}$ & $\begin{array}{l}47.14 \\
\pm 7.21\end{array}$ & $\begin{array}{l}44.22 \\
\pm 5.68\end{array}$ & $\begin{array}{l}45.23 \\
\pm 5.46\end{array}$ & $\begin{array}{l}45.57 \\
\pm 7.22\end{array}$ & $\begin{array}{l}47.61 \\
\pm 7.29\end{array}$ & $\begin{array}{l}46.34 \\
\pm 5.21\end{array}$ & $\begin{array}{l}42.11 \\
\pm 5.85\end{array}$ & $\begin{array}{l}45.33 \\
\pm 6.51\end{array}$ & $\begin{array}{l}45.34 \\
\pm 5.78\end{array}$ & $\begin{array}{l}45.34 \\
\pm 5.09\end{array}$ \\
\hline
\end{tabular}

Note: Comparison with the control group, $\boldsymbol{\Delta} P<0.05$

\section{Comparison of Related Index}

The degree of satisfaction and the satisfaction with self-help are both $98.88 \%$ in the experimental group, and compared with the control group, the increase was significant, and the difference was statistically significant $(P<0.05)$. The results were shown in table 4. 
Table 4 Comparison of related index

\begin{tabular}{|c|c|c|c|c|c|c|c|c|c|c|c|}
\hline \multirow{2}{*}{$\begin{array}{l}\text { Group } \\
\mathrm{s}\end{array}$} & \multirow{2}{*}{$\begin{array}{l}\text { Cas } \\
\text { es }\end{array}$} & \multicolumn{5}{|c|}{ The degree of satisfaction } & \multicolumn{5}{|c|}{ Satisfaction with self-help } \\
\hline & & $\begin{array}{l}\text { Very } \\
\text { satisfa } \\
\text { ction }\end{array}$ & $\begin{array}{l}\text { Satis } \\
\text { facti } \\
\text { on }\end{array}$ & $\begin{array}{l}\text { Com } \\
\text { mon } \\
\text { ly }\end{array}$ & $\begin{array}{l}\text { No } \\
\text { satisfa } \\
\text { ction }\end{array}$ & $\begin{array}{l}\text { Degree of } \\
\text { satisfaction } \\
(\%)\end{array}$ & $\begin{array}{l}\text { Very } \\
\text { satisfa } \\
\text { ction }\end{array}$ & $\begin{array}{l}\text { Sati } \\
\text { sfac } \\
\text { tion }\end{array}$ & $\begin{array}{l}\text { Com } \\
\text { mon } \\
\text { ly }\end{array}$ & $\begin{array}{l}\text { No } \\
\text { satisfa } \\
\text { ction }\end{array}$ & $\begin{array}{l}\text { Degree of } \\
\text { satisfactio } \\
\mathrm{n}(\%)\end{array}$ \\
\hline $\begin{array}{l}\text { Exper } \\
\text { iment } \\
\text { al } \\
\text { group }\end{array}$ & 89 & 48 & 33 & 7 & 1 & 98.88 & 42 & 39 & 7 & 1 & 98.88 \\
\hline $\begin{array}{l}\text { Contr } \\
\text { ol } \\
\text { group }\end{array}$ & 92 & 20 & 36 & 19 & 17 & $81.52^{\mathbf{\Lambda}}$ & 16 & 30 & 24 & 22 & $76.08^{\wedge}$ \\
\hline
\end{tabular}

Note: Comparison with the control group, $\Delta P<0.05$

\section{Discussion}

\section{The Influence of Case Analysis on the Mental Health of College Students}

Previous mental health courses were focused on theoretical education, while neglecting the grasp and teaching of their psychological quality. However, as far as college students, the fundamental purpose of psychological health education was to improve their overall psychological quality in order to cope with pressure and frustration [6]. Case analysis through the establishment of scene drama, interactive discussion, etc. thus causing the students to experience bad emotions, stress, frustration, etc. so as to construct correct knowledge and perception of mental health. Compared with the past, case analysis was more in line with the aim of the mental health education curriculum [5]. The results of this study indicate that, before the intervention, there was no difference in the score of CCSMHS between the two groups, $P>0.05$. After the intervention, compared with the control group, all the factors in the experimental group were significantly lower and the difference was statistically different, $P<0.05$.

The reason may be that the design of case analysis was more reasonable, and it was convenient to construct a positive curriculum atmosphere. Case analysis emphasizes experience in various activities and the process of their growth. The activities designed in the case analysis including drama and film appreciation. It not only increases the chances of communicating with the team members and enhances their psychological experience, but also makes them more deeply aware of themselves, understands others, and promotes self-reflection and understanding [6]. On the other hand, the real social situation in case analysis can better promote learning and practice. Moreover, the premise of a successful case analysis was reasonable design. The teaching plan in this study was based on the collection and arrangement of topics of interest to college students, and drafted after discussed by the professional psychology teachers. The teaching plan strives to interesting coexistence of pertinence and practicability, and in a good atmosphere, the students will devote themselves to their self, release their emotions and gain mental growth.

\section{The Intervention Effect of Case Analysis on College Students' Mental Health}

The results of this study showed that the degree of satisfaction and the satisfaction with self-help are both $98.88 \%$ in the experimental group, and compared with the control group, the increase was significant, and the difference was statistically significant $(P<0.05)$. This may be due to the better integration of mental health knowledge into teaching methods such as emotional experience and behavioral training through case-based analysis, and not only to gain knowledge, but also to pay more attention to emotion and behavior, and unified the knowledge, emotion and action. Compared with the previous mental health intervention model, which emphasizes the theory and neglects the student's experience, it can make the students get empathy more [7].

In summary, the application of case analysis in college students' mental health education can 
improve students' mental health and improve the effect of intervention. But in the experimental group of this study, there was a student who was not satisfied with the model. And after talking to him, it was found that the student was more introverted, excluded from communication activities, and had serious communication obstacles. After communicating with the psychological consultation teacher in this school, we're going to intervene his mental health and relevant observations will be made in the future.

\section{Acknowledgment}

This project was from Humanities and Social Sciences Research Project of Education Department of Heilongjiang province (College student work project), the project numbers was 1253xs337.

\section{Reference}

[1] Chu YJ. The application of experiential teaching model in college Japanese teaching[J]. Education Exploration, 2012, 26(1):29-31.

[2] Qiu XY, Song HF. Experimental study on experiential teaching of psychological health education for College Students[J]. Journal of Educational Science of Hunan Normal University (Higher education research), 2013, 12(1):95-98.

[3] Research group on mental health evaluation system of Chinese college students under the ministry of education, mental health scale for Chinese college students (CCSMHS), Handbook of mental health assessment system for Chinese college students[R]. 2005, 6.

[4] Shen HQ. Case analysis on promoting college students' psychological crisis intervention[J]. China Education Innovation Herald, 2014, 35(4):247-248.

[5] Wang YH. Comparative Analysis on the effectiveness of different teaching methods of mental health education in colleges and universities[J]. Chinese Journal of School Health, 2014, 35(6):832-833.

[6] Wang JY. The application of experiential teaching in the course of college students' mental health education[J]. Journal of Heihe University, 2016, (2):62-64.

[7] Zheng XQ, Li L. On the Integration of psychological health education and ideological and political education in colleges and universities[J]. Journal of Guangxi Normal University (Philosophy and Social Sciences Edition), 2011, 21(4):126-131. 